\title{
Development of Hybrid Propulsion System for Energy Management and Emission Reduction in Maritime Transport System
}

\author{
Reza Karimpour ${ }^{1}$, Maryam Karimpour ${ }^{2}$ \\ ${ }^{1}$ Ocean-Going Ship Chief Engineer, Islamic Republic of Iran Shipping Lines (IRISL), Tehran, Iran \\ ${ }^{2}$ Electronic Engineer, Master of IT, Tehran Branch, Azad University, E-Campus, Tehran, Iran \\ Email: rezakarimpour61@gmail.com, mary.karimpour@gmail.com
}

How to cite this paper: Karimpour, R. and Karimpour, M. (2016) Development of Hybrid Propulsion System for Energy Management and Emission Reduction in Maritime Transport System. Open Journal o1 Marine Science, 6, 482-497.

http://dx.doi.org/10.4236/ojms.2016.64040

Received: July 19, 2016

Accepted: September 27, 2016

Published: September 30, 2016

Copyright (c) 2016 by authors and Scientific Research Publishing Inc. This work is licensed under the Creative Commons Attribution International License (CC BY 4.0).

http://creativecommons.org/licenses/by/4.0/ (c) (i) Open Access

\begin{abstract}
Given the strategic importance of energy and air pollution in the today world and due to the fact that the maritime transport system is one of the main sources of energy consumption and emissions in the environment, particularly contamination of water, so in recent years, fuel consumption and emissions reduction in the maritime transport industry has received considerable attention. Thus, in this paper, a new method is provided for typical boat hybridization, so by adding an electric motor and battery to boat power transmission system, dynamic performance will improve fuel consumption and emissions reduces. For this purpose, power transmission system elements are modelled and boat function is evaluated in real terms of movement by defining energy management strategy between power sources. The simulation results show that boat hybridization considerably reduces fuel consumption and emissions.
\end{abstract}

\section{Keywords}

Electric Hybrid Boat, Energy Management, Fuel Consumption, Emissions

\section{Introduction}

Due to issues such as air pollution and rising fossil fuel prices, governments, industry and researchers try to find a suitable alternative for conventional maritime transport. It is expected that hybrid and electric boats and ships are one of the key technologies of marine industries [1] [2]. For this reason, research about marine hybrid vehicles and their development and production is necessary. Shipping is a very necessary issue in the global economy and has a substantial contribution especially in shipping export and 
import. Unfortunately, the industry is considered as one of the main reasons for increasing the pollution. According to report of Europe Union by 2020, emissions of sulfur dioxide (SOx and acid nitrogen (NOx) by ship will be much higher than other sources of pollution. Reducing these emissions is essential in order to protect shipping as one of the ways of carrying cargo and passenger. Fortunately, technology for reducing these emissions is available in shipping industry to the level of $80-90$ per cent. Another problem that leads to concentrating on this industry to reduce pollution levels is low cost of applying these technologies in this industry compared to on land industries. It should also be noted that, according to the report of Union of Europe in 2014, carbon dioxide gas production as the main emission gas has reached to more than 1000 million tons only in the Europe Union and in case of not taking any necessary action, it will be more than triple in 2050. America Energy Management Institute has shown fuel consumption and emissions for various industries in Figure 1 and Figure 2 [3].

As it is clear, $27 \%$ of fuel consumption and $33.7 \%$ of air pollution in the world belongs to transport industry [4]. Also according to official figures released by the Department of America Energy, in usual engines, 15\% of the total fuel energy is used to propel the boat and its components, while most of the energy in the combustion process is wasted as heat and causes warming and air pollution. Energy consumption in the internal combustion engine is shown in Figure 3.

However, the electric motor uses $75 \%$ of its power for propulsion. Due to pollution caused by transport industry and constraints of fossil fuels, shipyards have taken an important step in dealing with this issue that among them hybrid vehicles, fuel cell technology, gasoline direct injection engine, compression ignition engines with homogeneous mixture and bi-fuel propulsion engines can be pointed. High efficiency, low emissions, high measurable distance, optimum safety and competitive price with conventional propulsion systems is among important features for hybrid transport system.

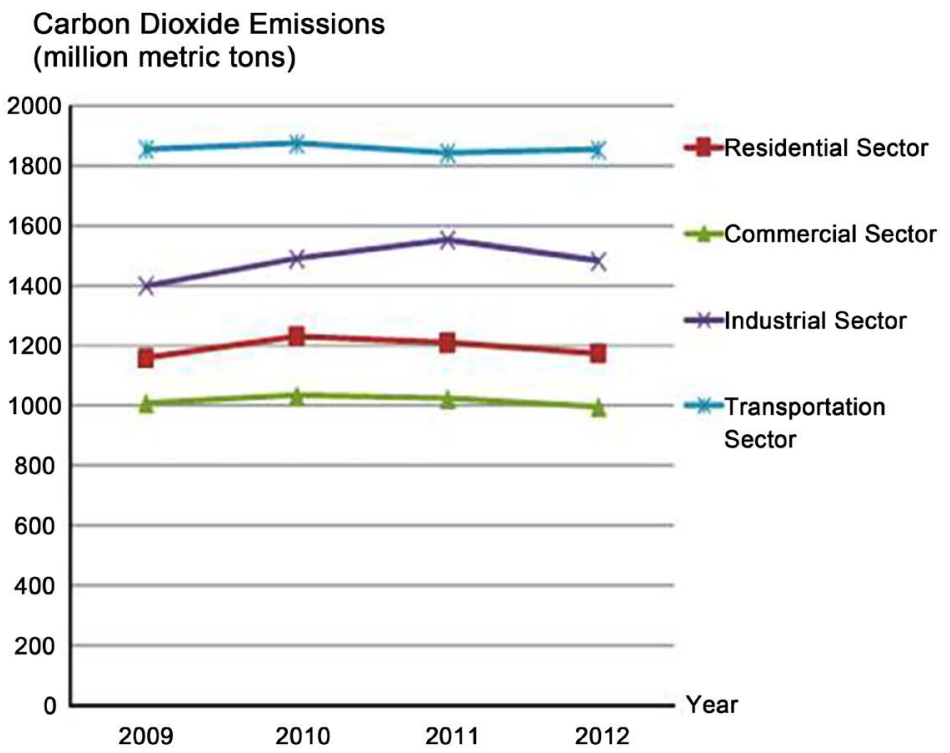

Figure 1. Emissions of various industries [4]. 


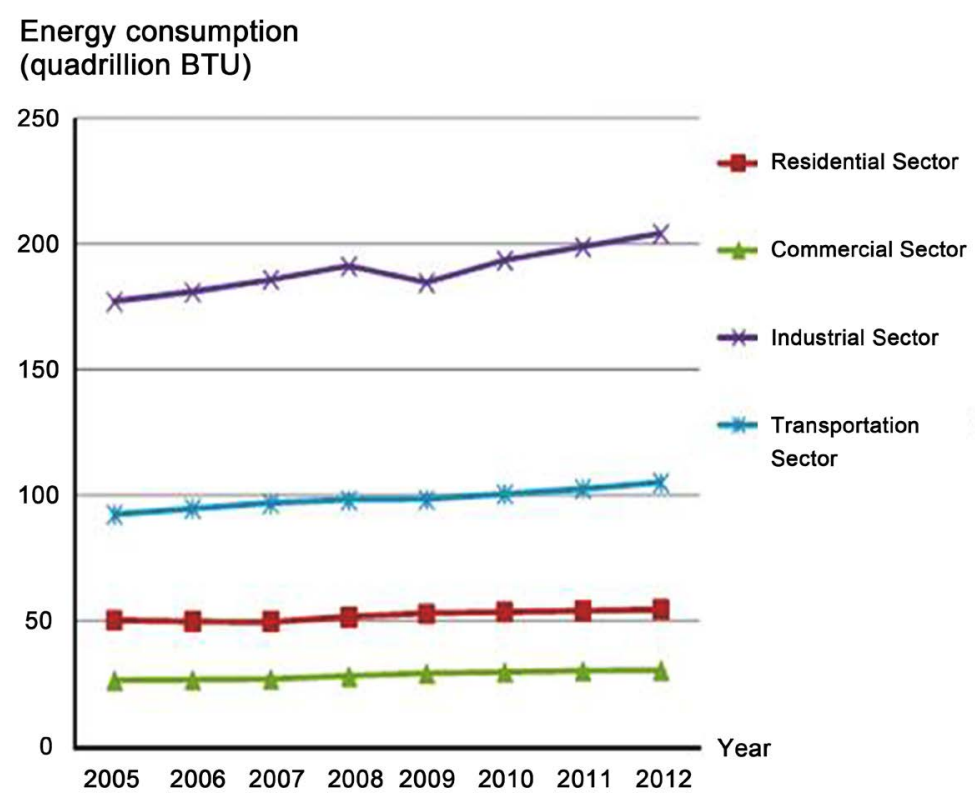

Figure 2. Fuel consumption in various industries [4].

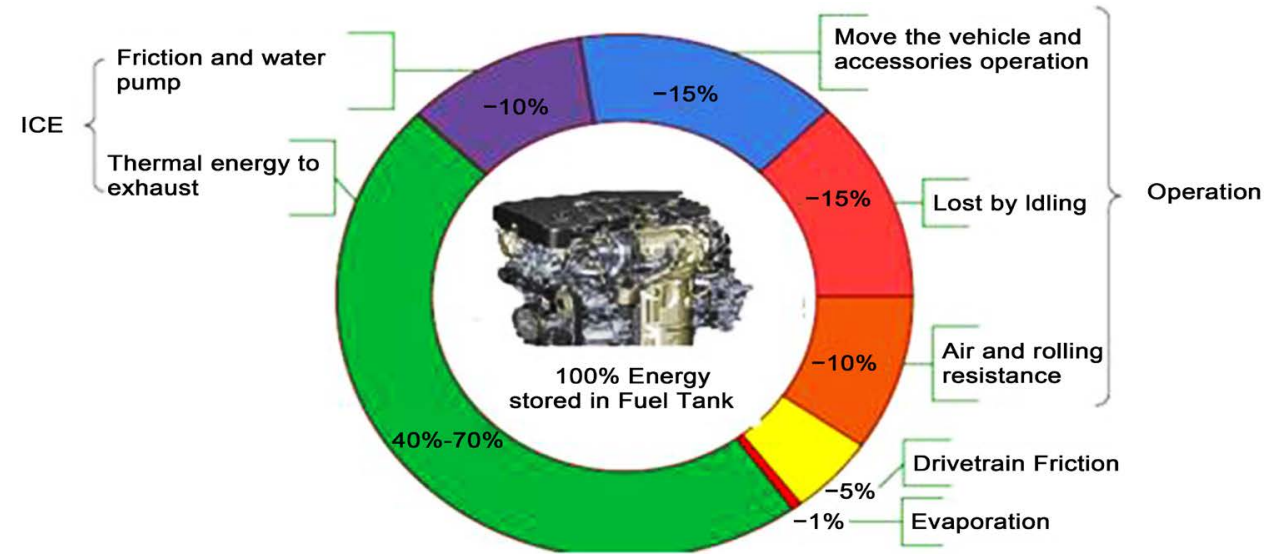

Figure 3. Fuel consumption in diesel engines.

\section{Literature Review}

Hybrid boats use at least two sources of energy to move. In new generation of hybrid boats, the internal combustion engine and electric motor provide propulsion for movement. One of the disadvantages of the internal combustion engine is that at low revs that output and efficiency is higher, they produce little power. Unlike internal combustion engines, electric motors at low revs produce much torque with high efficiency. So by putting these two motors together, enough power to move and acceleration is obtained and fuel consumption can also be reduced. One of the most interesting features of electric hybrid boats is that their battery is charged and provides required power when the internal combustion engine makes power more than the required amount to drive the boat or by direct application of engine power. So, one of the most important issues in the field of hybrid power transmission system is management and intelligent 
electronic balance of relationship between two motors with each other under different driving conditions [5]-[10]. In [10] a method is provided for sizing components of hybrid boats by using fuzzy control strategy and selection of component optimization. Their results indicate a significant improvement in fuel consumption of hybrid boats up to $33 \%$ without considering the effect of the pollution. This research is provided by the aim of studying the field of hybrid boats and their performance simulation in order to consider different structures and technologies of hybrid boats and offer related simulation results in reducing fuel consumption and emissions from maritime transport system and its environmental impact.

\section{Modeling Electric-Diesel Hybrid System Components}

Hybrid power transmission systems are pure electrical generalized types that their pure electric disadvantages largely have been resolved and it can be said that disadvantages of internal combustion engines have been resolved to some extent in them too. One of the key advantages of these power transmission systems compared to diesel engine is operating in the fixed charge and rev and working on its optimum point which increases engine efficiency and reduces pollution and fuel consumption. Also when braking or stopping, energy is electronically stored in batteries through a Regenerative Braking energy system, and this causes lower performance of combustion engine which consequently leads to a reduction in pollution and fuel consumption. Hybrid boats have different structures. But a hybrid boat is made from an energy storage system, a power generation unit and a power transmission system (Figure 4).

1) Diesel engine: engine in hybrid boats is similar to diesel engines in conventional cars. However, this engine is smaller and uses advanced technologies compared to con-

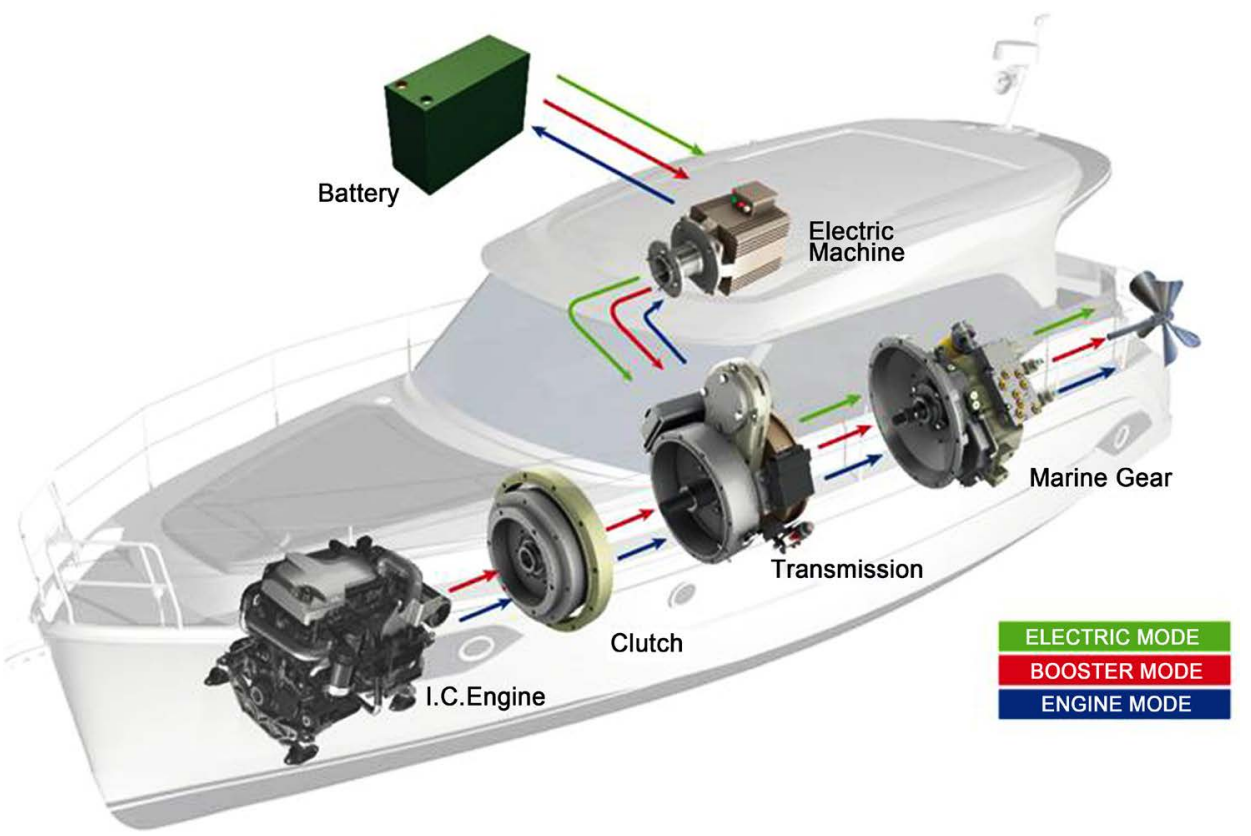

Figure 4. Schematic of hybrid boats components. 
ventional vehicles that reduces emissions and increases efficiency. Figure 5 shows categories of different transmission systems from the perspective of the hybridization (electrical power to total power).

2) Electric motors: electric motors in hybrid boat are able to work both as a motor and as a generator. For example, when the engine is required, the engine can use batteries to create momentum, and when the boat does not need electric motor, for example, in a moving downhill, the electric motor returns power to the battery as a generator.

3) The energy storage system: the energy storage system in hybrid boats can be batteries, flywheels, ultra-capacitors and hydrogen fuel. The most widely used energy storage is battery. The most important characteristic of batteries is its capacity that is measured by Ah. Also, stored energy in the battery (capacity per average draining voltage of battery) that is measured based on the watt-hour, is the main characteristics of the battery. Another parameter that affects the performance of battery and choosing it is the state-of-charge that is expressed as percentage. Suitable batteries are shown in Table 1.

The battery are divided into 5 groups named acid, nickel, lithium, sodium and air insulation batteries on the basis of their material and performance. The cheapest and

1. Internal Combustion Engine (ICE) 2. Micro-Hybrid Electric Vehicle

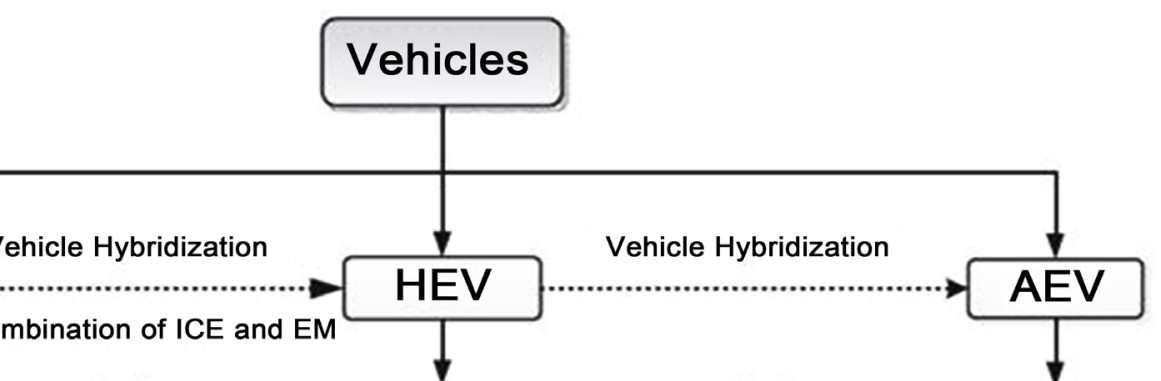

1. Mild-Hybrid Electric Vehicle

2. Full Hybrid Electric Vehicles (Full-HEV) -Extended range Electric Vehicle (EREV) - Parallel Hybrid Electric Vehicle - Series Hybrid Electric Vehicle

- Complex Hybrid Electric Vehicle

- Plug-in Hybrid Electric Vehicle (PHEV)
1. Battery Electric Vehicle (BEV)

2. Fuel Cell Electric Vehicle (FCEV)

Figure 5. Categories based on the degree of hybridization.

Table 1. Types of batteries [11].

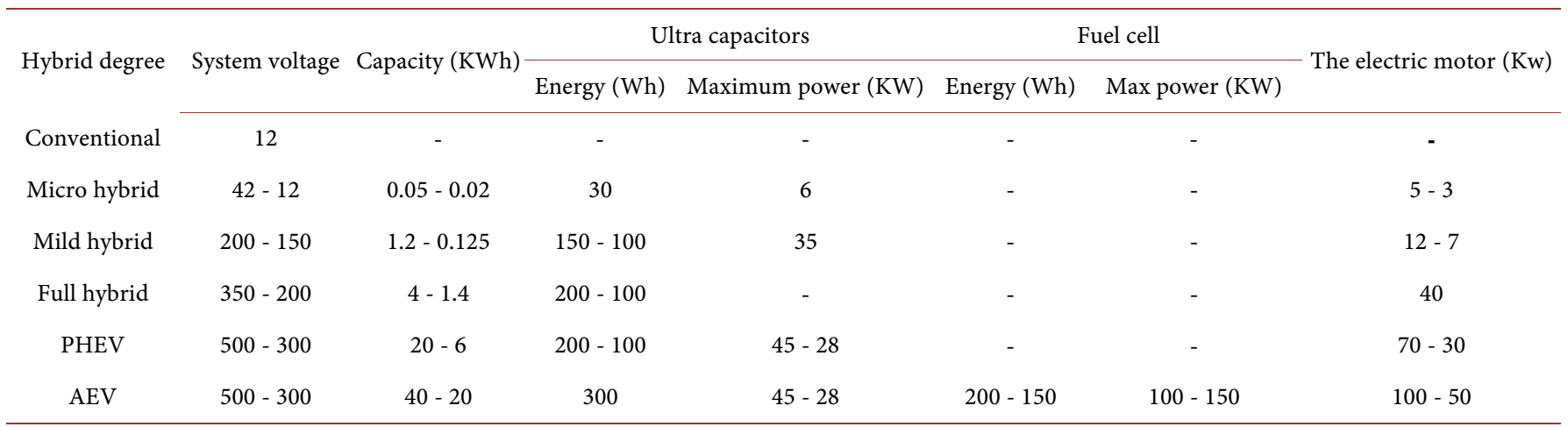


most available battery in conventional diesel boats is acid batteries. These batteries not only have high weight but also in production and application process cause environmental pollution and are not used in hybrid systems [11]. Although nickel batteries such as nickel-zinc and nickel-Cadmium are environmentally compatible, but have heavy weight, high maintenance costs and high discharge rate [12]. Zero-emission batteries that have been made from sodium nickel chloride are characterized by high temperature in the range of $350^{\circ} \mathrm{C}-500^{\circ} \mathrm{C}$ and have a higher charge level and a longer life compared to other battery, but when are not used, lose energy equal to $90 \mathrm{w}$ [12].

Lithium batteries with long life, light weight and high energy level of the charge are the most commonly used batteries in hybrid boats. Also the material of lithium batteries is not toxic substances such as lead or cadmium. But the high cost of producing this battery is one of its disadvantages. Nowadays lithium-sulfur batteries among lithium batteries give the highest energy level in low weight.

Polymer lithium batteries have high compliance capabilities for locating and various significance levels, but offer low conductivity and energy power.

Another lithium battery is lithium-iron-phosphate battery that has higher discharge current and along with, has high thermal and chemical properties that shows better protection properties.

One other type of batteries is zinc-air battery that has higher characteristic energy and energy density than lithium batteries. Its disadvantages include large density, low power characteristic and life span. Today, a lot of research has been done for commercialization of this type of battery [11].

\section{The Powertrain System}

The powertrain system in hybrid boats can be continuous, automatic and manual automatic. Type of power train system and its optimization could play an important role in fuel consumption and performance of hybrid boats.

\section{The Hybrid Control System}

The purpose of the control strategies in hybrid electric boats is optimized energy management, reducing pollution and fuel consumption, replacement of the diesel engine and electric motor and batteries to areas with maximum efficiency to meet the above objectives and meet the boat driving ability. In general, two types of control strategies for hybrid control system that is named rule-based control and Optimization approach control. Rule-based control works based on experimental data, mathematical model, specifications and load balancing strategies in the boat and is divided into two categories of crisp and fuzzy control [13].

On/off control is one of the simple controls with high certainty which is used in Advisor software by default. Control with optimization strategy uses numerical solution for minimizing the objective function (fuel consumption, emissions or zinc slope) and linear programming control, optimal control, dynamic programming, genetic algorithms and adaptive fuzz can be noted in this regard (Figure 6). 


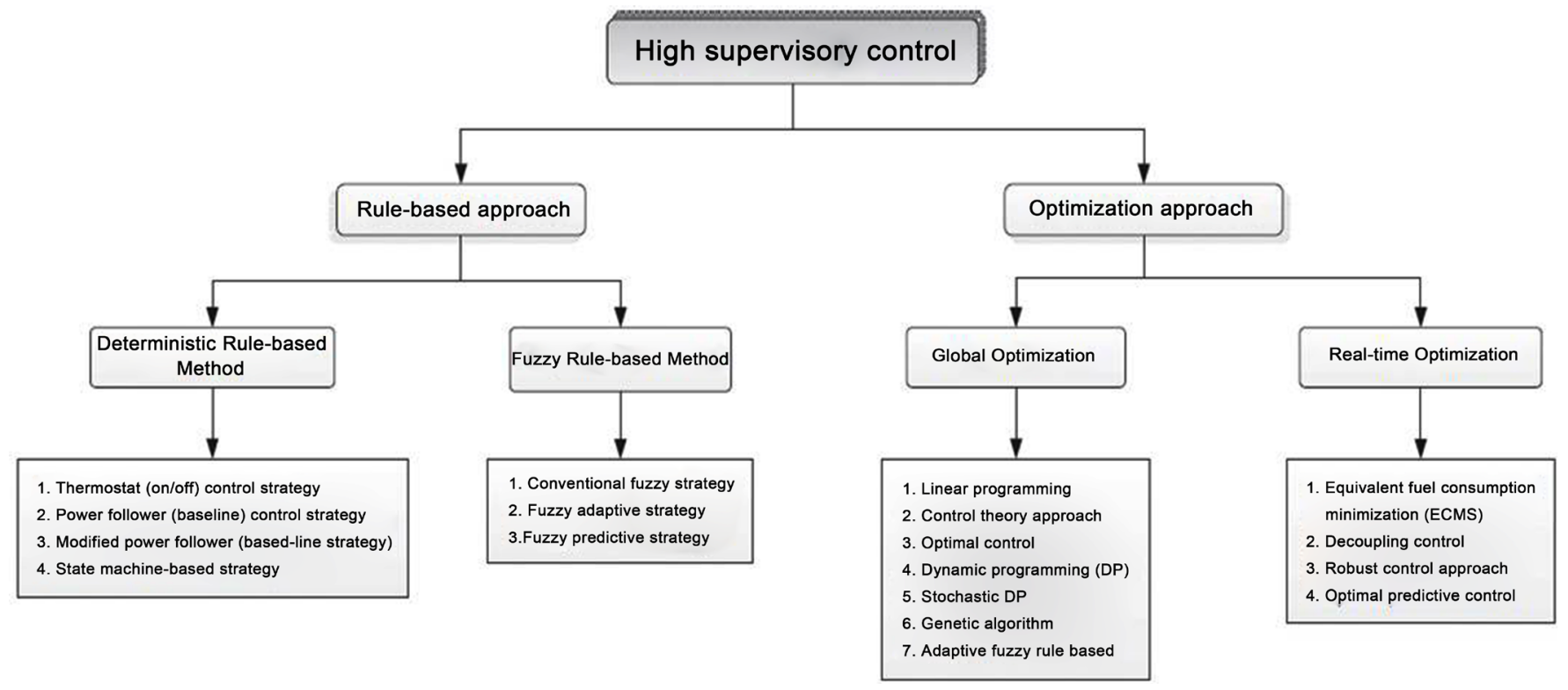

Figure 6. Overall categories of control strategy.

In general, strategic management of power (energy) current in hybrid is divided to three-stage of battery discharge, battery charging and braking. In the first case, as shown in (Figures 7-9), the battery works as a primary source of energy, and when the required power exceeds the capacity of the battery, the internal combustion engine is activated to compensate for energy. In the second phase of the battery charging, generator/the internal combustion engine will be considered as an energy source. When the state-of-charge is less than the minimum required, internal combustion engine uses extra power to recharge the battery. In the recovery stage of waste energy, energy recovery system is activated to receive braking energy and suspension system fluctuations. When renewable energy is greater than the required amount to store, it is wasted frictionally [14].

\subsection{Categories of Powertrain Hybrid System Structure}

Hybrid system generally is divided into three categories of series, parallel and seriesparallel (hybrid), based on the required structure and performance.

\subsection{Series Hybrid Structure}

In these hybrid systems, combustion engine turns a generator, and this generator charges the battery and moves the electric motor and so the transfer of power can occur. In this structure, the diesel engine is not connected directly to the power transmission system [15].

This system is called series, because the power is used for propulsion in series and is used for propulsion of engines with low power and optimum working range. In this article, according to the proper functioning of this structure in marine vessels, for modeling hybrid boat, kind of series that are more common have been used (Figure 10). 


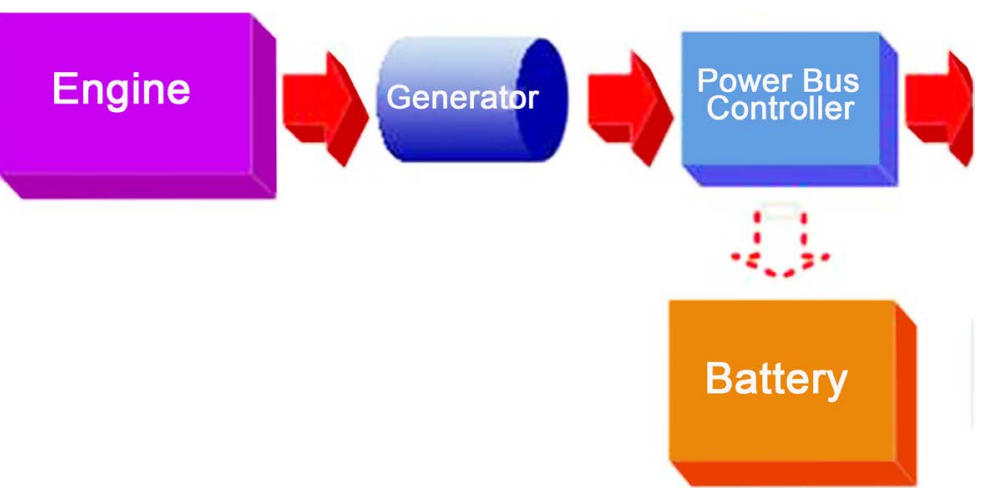

Figure 7. The flow of energy in the starter phase.

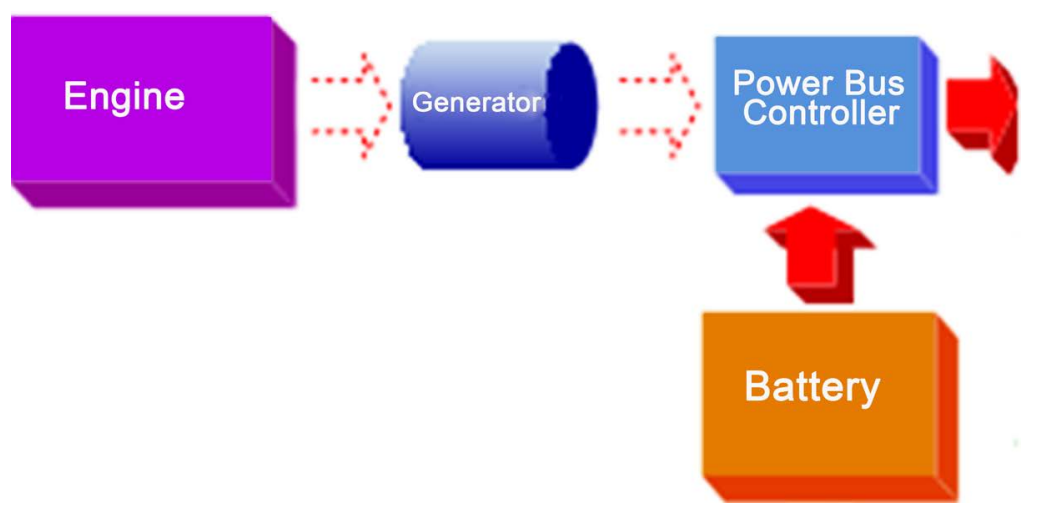

Figure 8. Battery charge and activated internal combustion engine.

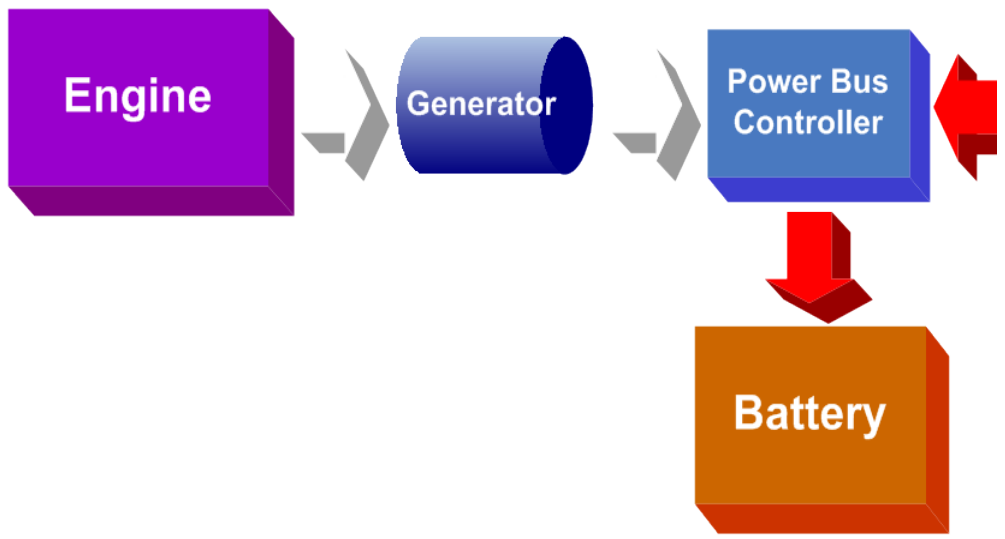

Figure 9. Energy recovery mode.

\subsection{Parallel Hybrid System}

In this type of system, diesel engine and electric motor move the boat in parallel. In this system, electric motor feeds from battery and diesel engine feeds from fossil fuel sources directly. In this case the generator has been removed and battery is charged by switching electric motor mode to generator. Since this system has only one engine, electric engine cannot recharge the battery and create propulsion at the same time Parallel hybrid structure diagram is shown in Figure 11. 


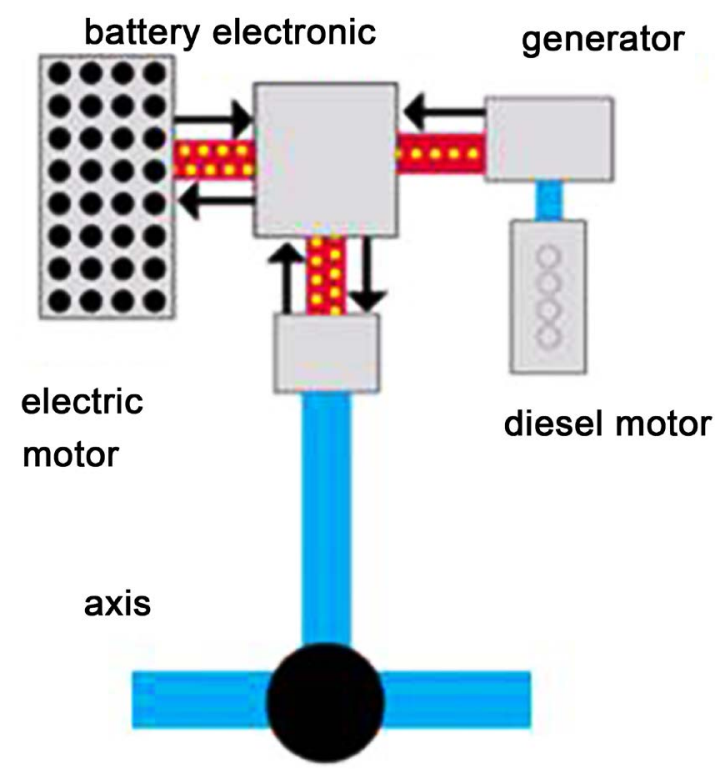

Figure 10. Structure of series hybrid.

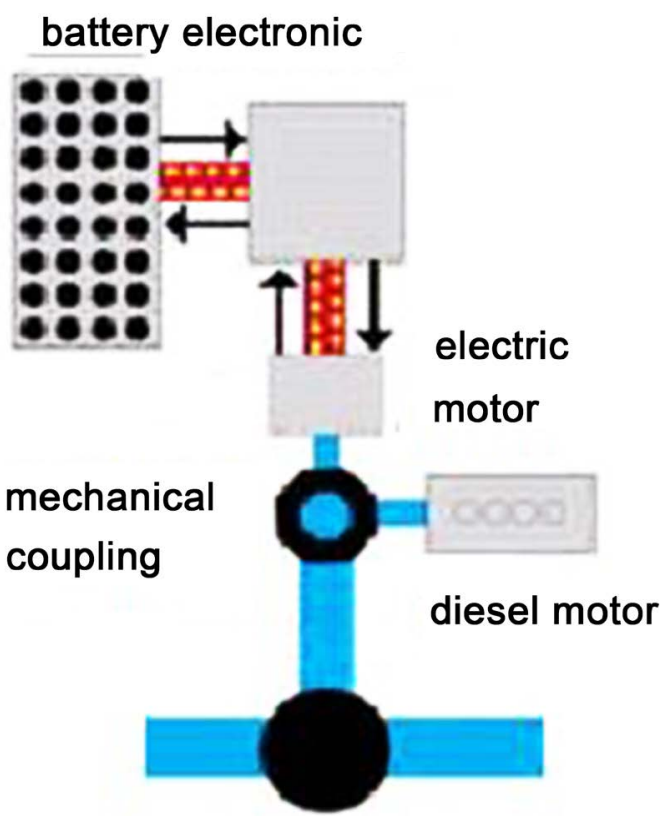

Figure 11. Parallel hybrid structure.

\subsection{Series-Parallel Hybrid System}

The design is such that it can be used in different situations for series or parallel hybrid. In this system, by using advanced technology, the possibility of using the ignition system and electrical system is possible separately and simultaneously, so it can be independently combustion or a combination of the two systems in fully electric and not polluted urban situations at high speeds and in rural areas. In situations such as rapid acceleration, both systems operate together. Such systems are usually mixed and by using a suitable control strategy, they keep state-of-charge in a good situation in practice 
along with providing good performance. In this system, there are two electric motors and depending on conditions, their combination can be used, and they have the ability to convert the generator too (Figure 12).

In different movement situations and according to different criteria, three types of series hybrid, parallel hybrid and combination hybrid are compared in Table 2.

Another type of hybrid boat categories can be expressed based on the use of electric power. For optimal hybridization, optimal proportion of use of electric power and internal combustion engine must be identified, so by using optimum values of these indicators in different situations, fuel consumption and emissions can be reduces. The degree of hybridization is expressed as the ratio of consumption electric power to total power, according to Equation (1)

\section{Simulations and Results}

For a hybrid power train system with a $532 \mathrm{~kW}$ diesel engine characteristics, simulation of the electric motor of $670 \mathrm{~kW}, 501 \mathrm{~kW}$ generator and lithium battery with 130 module was conducted. Simulating fuel consumption, emissions and battery life for a variety of power train system and batteries are compared. In next stage, hybrid boat simulation is conducted based on component selection of power train system and results have been offered. Charges of state-of-charge have been compared for two types of hybrid structure in the Figure 13 for various maneuvers.

Figure 13 shows that for hybrid boats, charges of state-of-charge for hybrid boat is

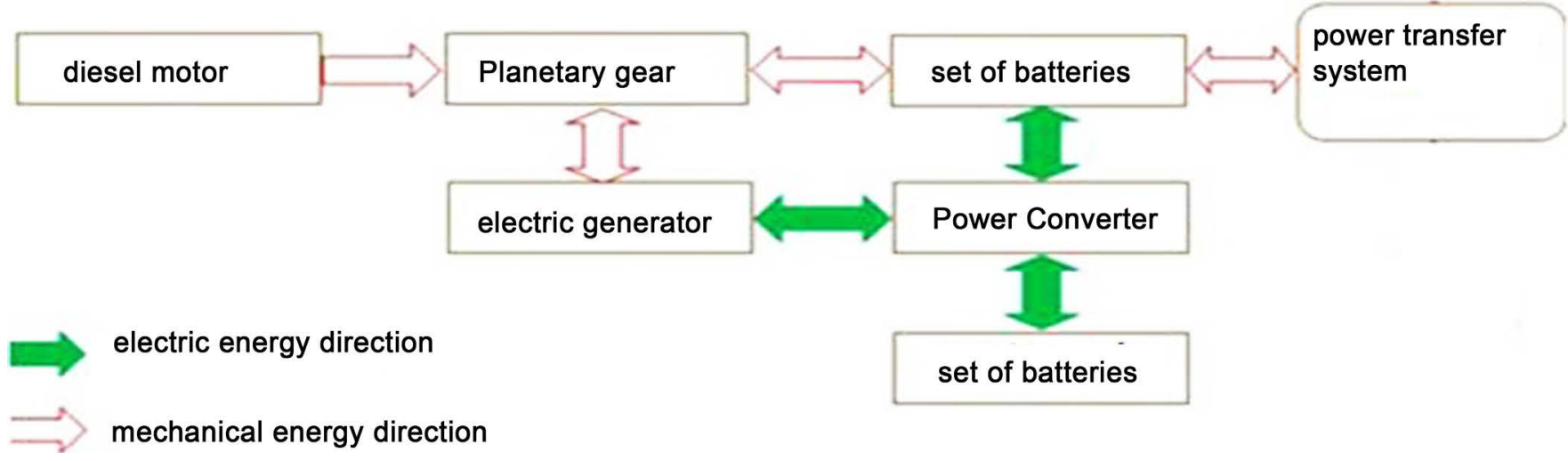

Figure 12. Combined structure.

Table 2. Comparison of hybrid structure performances.

\begin{tabular}{cccccc}
\hline \multirow{2}{*}{$\begin{array}{c}\text { Hybrid system } \\
\text { comparison }\end{array}$} & Improving fuel consumption & \multicolumn{2}{c}{ Driving performance } \\
\cline { 2 - 6 } & Idling stop & Energy recovery & $\begin{array}{c}\text { High efficiency } \\
\text { operation control }\end{array}$ & Total efficiency & Acceleration \\
\hline Series & $\bullet$ & $\boldsymbol{0}$ & $\bullet$ & $\bullet$ & 0 \\
harallel & $\bullet$ & $\bullet$ & 0 & $\bullet$ & 0 \\
Series-parallel & $\mathbf{0}$ & $\mathbf{0}$ & $\mathbf{0}$ & $\mathbf{0}$ & $\bullet$ \\
\hline
\end{tabular}

Weak O, Good $\mathbf{0}$, Very Good $\bullet$. 

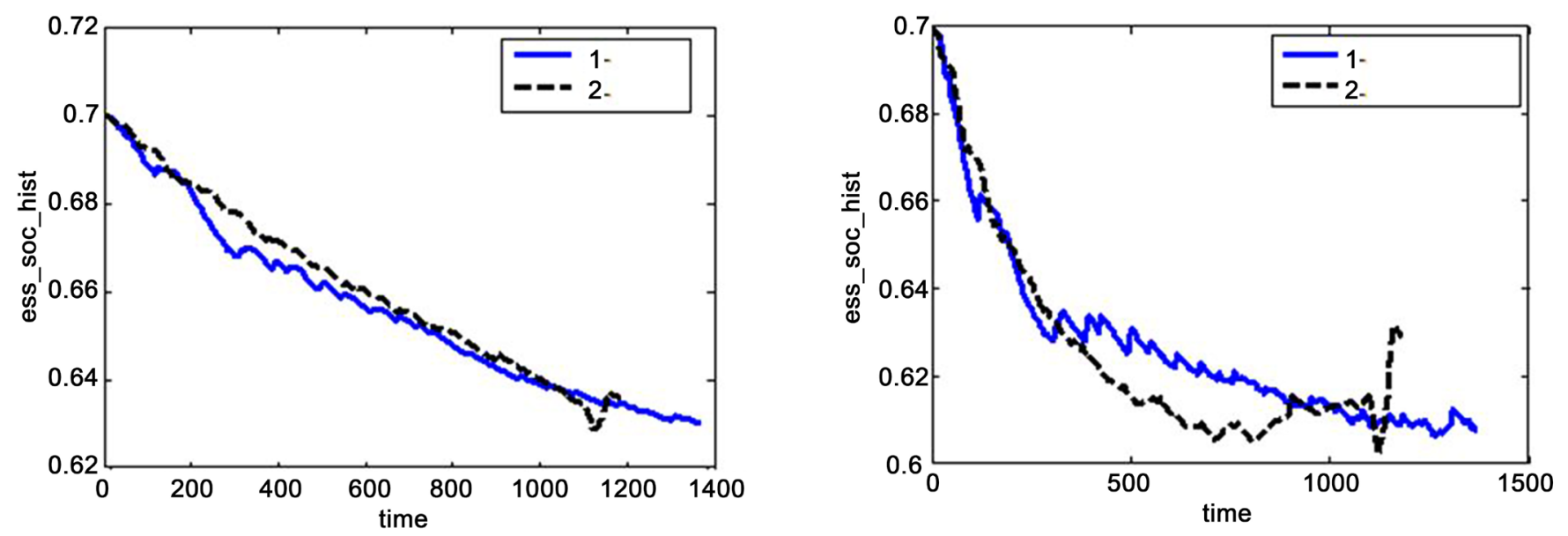

Figure 13. Charges of state-of-charge for hybrid boats in various maneuvers.

faster than normal, the hybrid has a less charge level drop than usual ones and indicates greater use of electricity for propulsion. The effect of hybridization in torque and output power is shown in Figure 14 and Figure 15.

Also, the graph of engine output torque in different revs is shown Figure 16 and the graph of engine output power in different revs is shown Figure 17.

According to Figure 17, this engine produces very suitable torque and power at low revs; so that it can improve mobility capabilities of boat.

Simulation results on the performance of the combustion engine and electric motor that is selected for hybrid boat is provided in Figure 18.

a) Combustion engine.

b) Electric motor.

The results of fuel consumption and emissions of hybrid boats with conventional boats is presented in Table 3 . Results show that boat hybridization can reduce emissions up to $20 \%$ and fuel consumption up to $27 \%$.

It is estimated that hybrid diesel-electric propulsion systems consume fuel at least $20 \%$ less than diesel systems on the same terms and with full load. Altogether, this fuel consumption saving is created from pilot power component that is obtained from renewable sources. This means producing fewer harmful gases at lower speeds and with little load. Figure 19 compares diesel and hybrid systems in terms of fuel consumption and polluting gas and the cost of using each of these systems.

\section{Conclusion}

In this study, the performance of various hybrid structures, including batteries and powertrain systems was investigated. Then, the boat hybridization impact was evaluated on fuel consumption, emissions and battery performance. The results show that by powertrain system hybridization, better performance in terms of fuel consumption, emissions and battery life can be achieved. The purpose of this article is boat hybridization and its impact on the boat longitudinal dynamics performance (fuel consumption and emissions production). Knowing the boat dynamic performance and environmental 


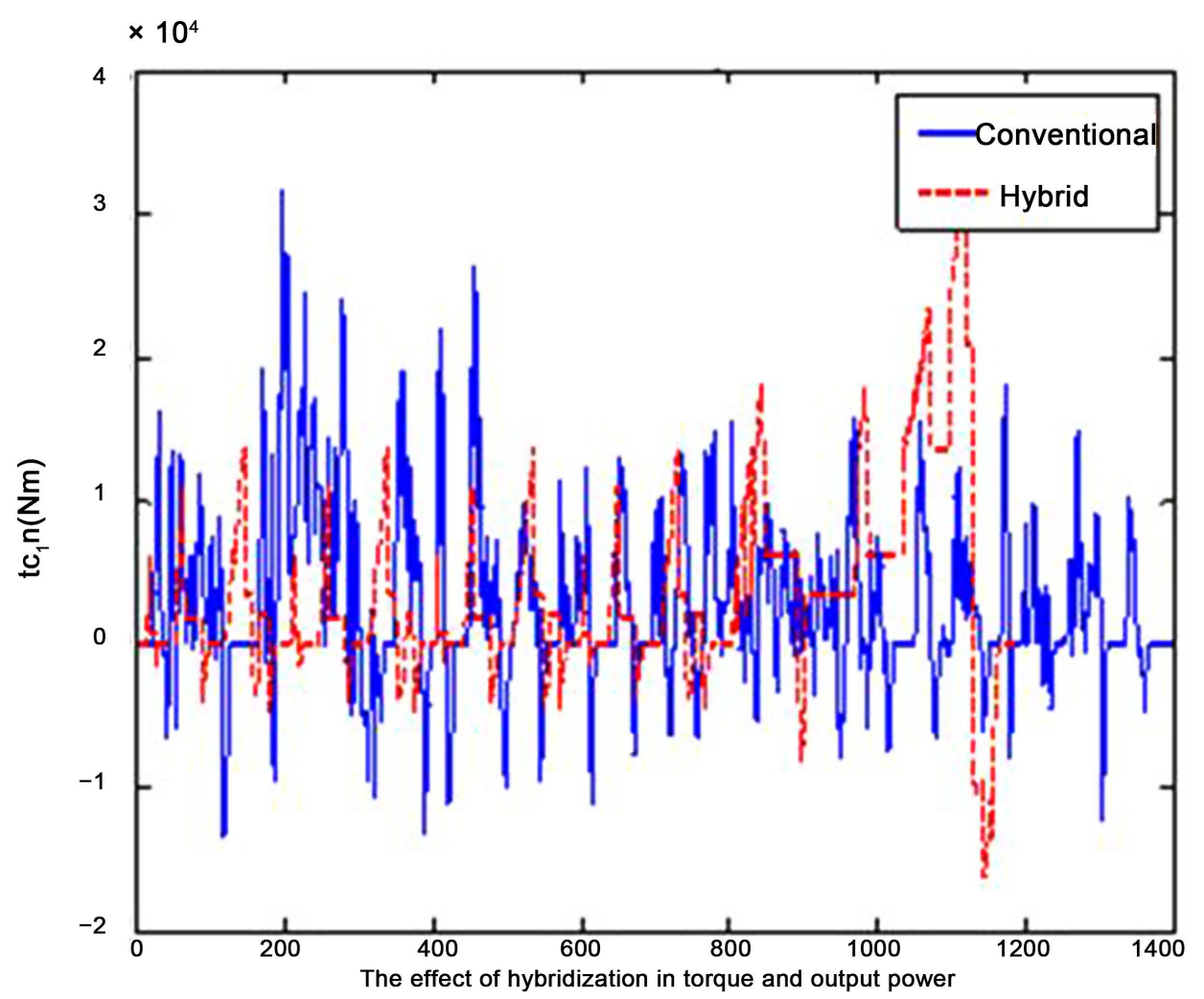

Figure 14. Required input torque.

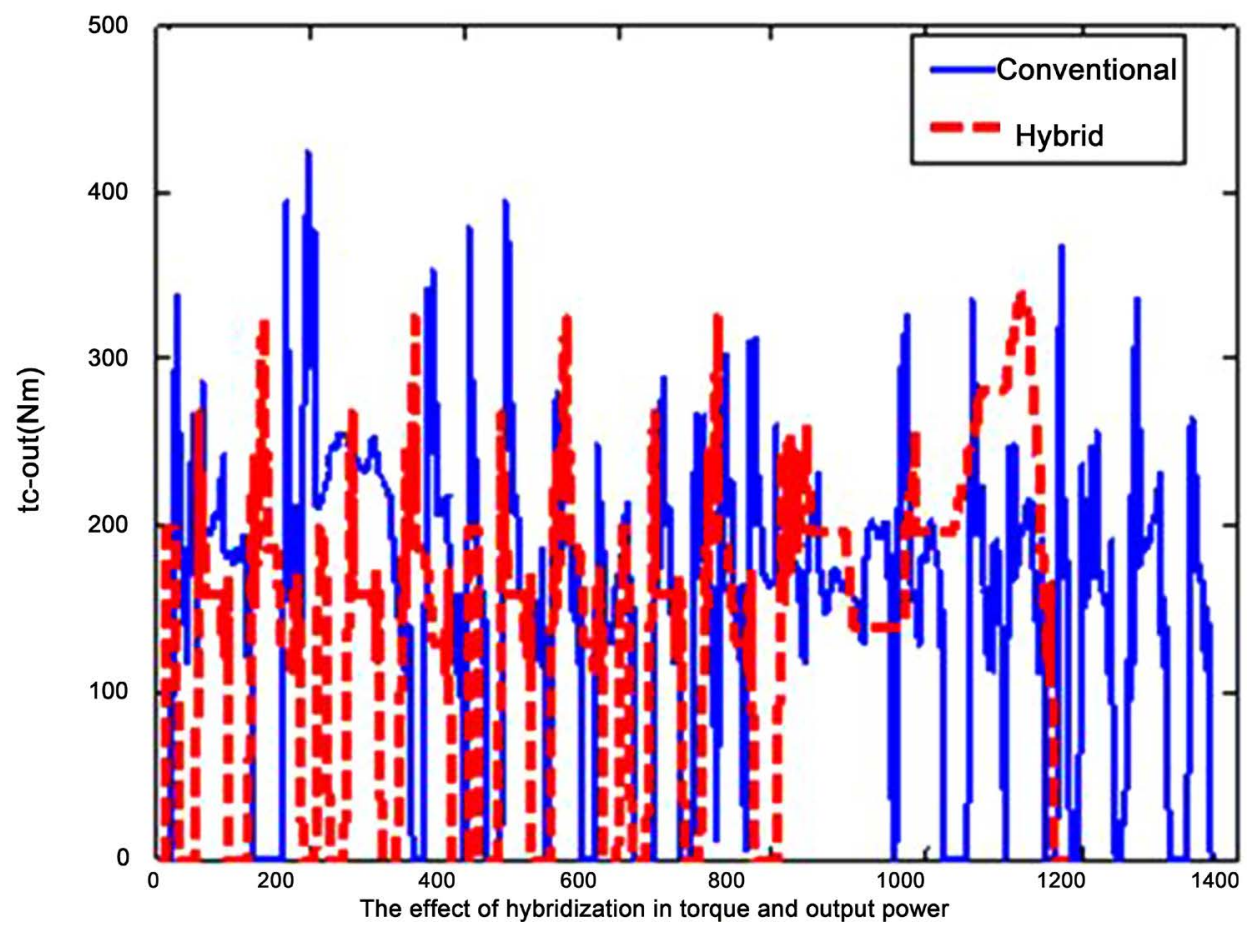

Figure 15. Required output torque.

impact and fuel consumption is very important. As laboratory equipment is expensive 


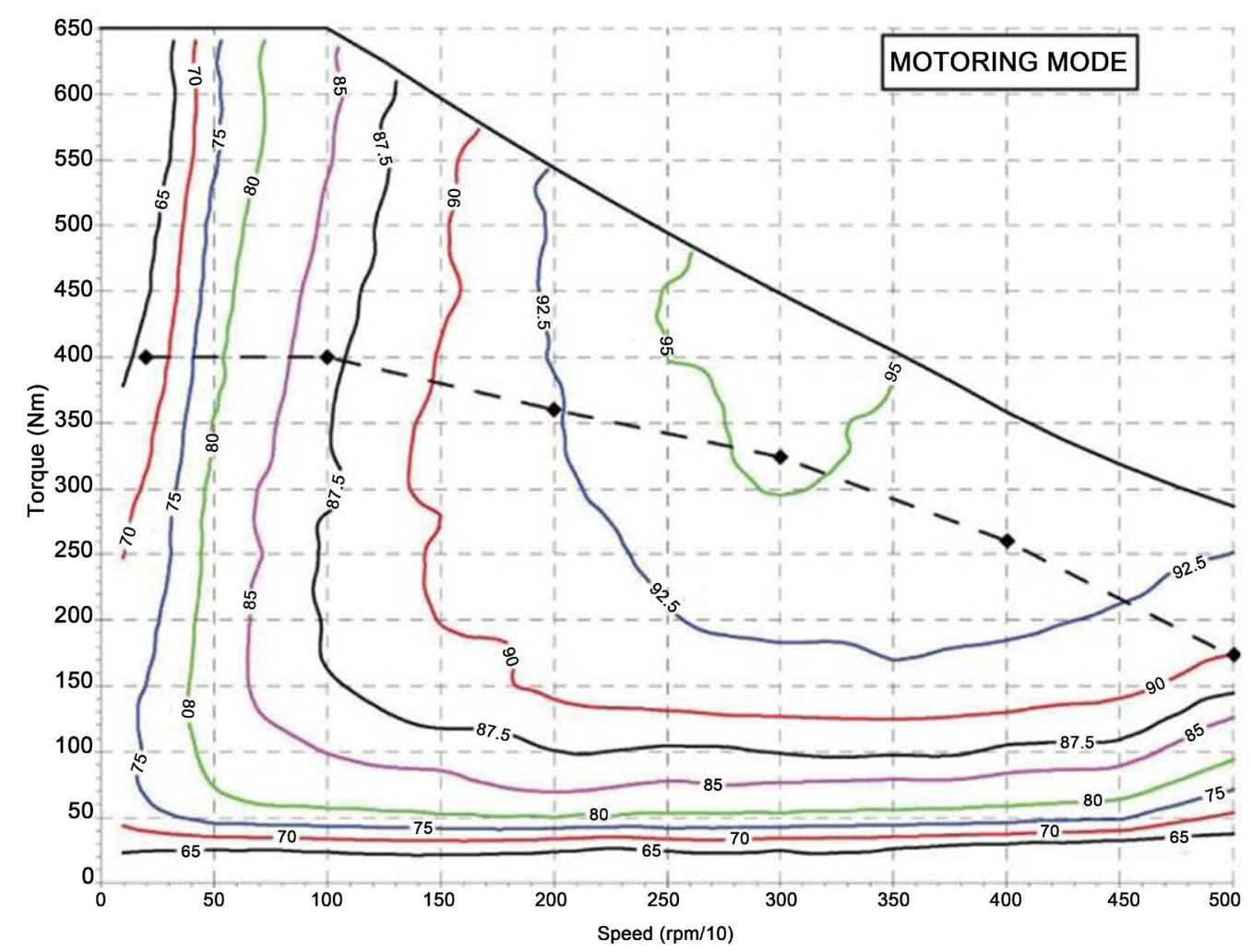

Figure 16. Engine output torque in different revs.

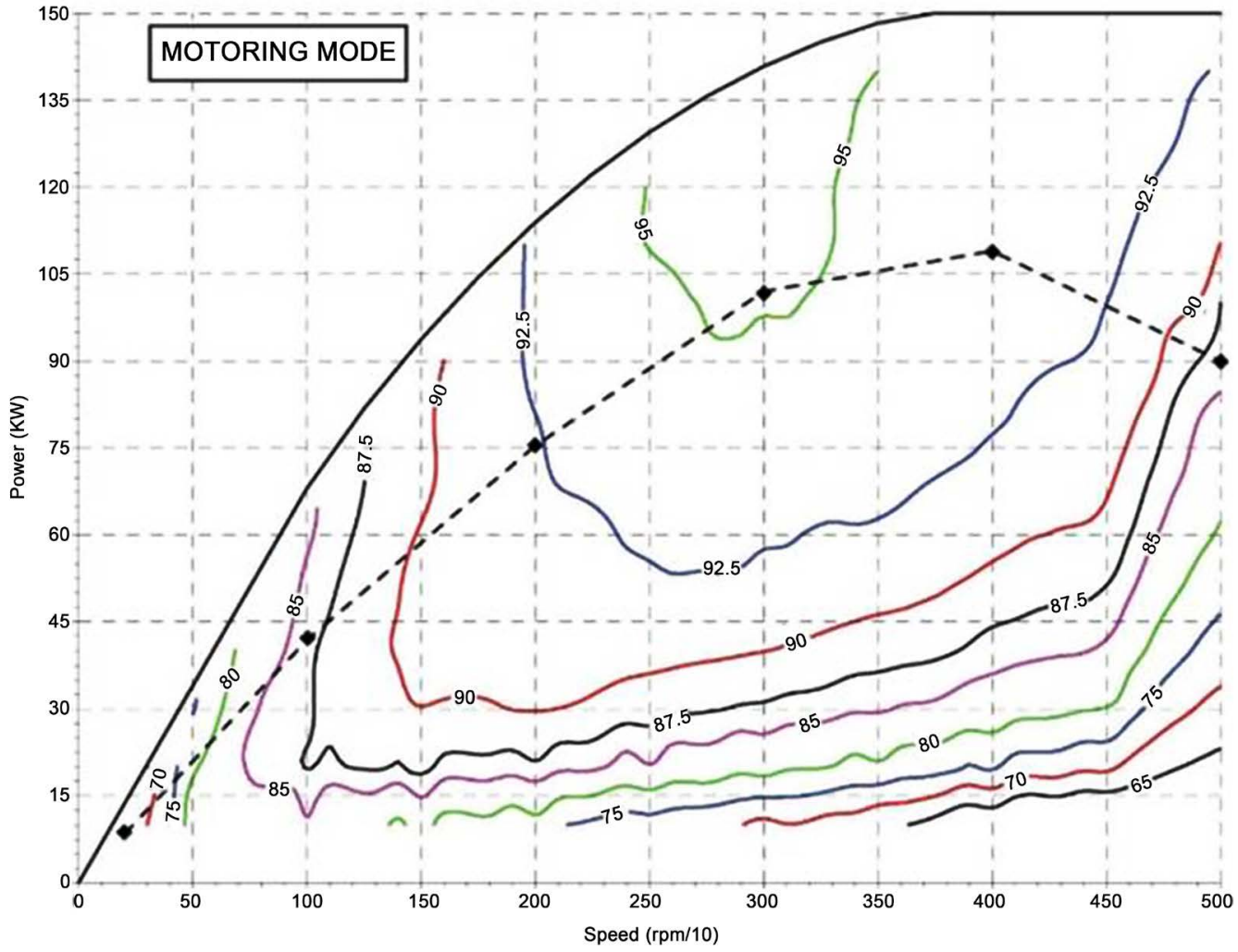

Figure 17. Engine output in different revs. 


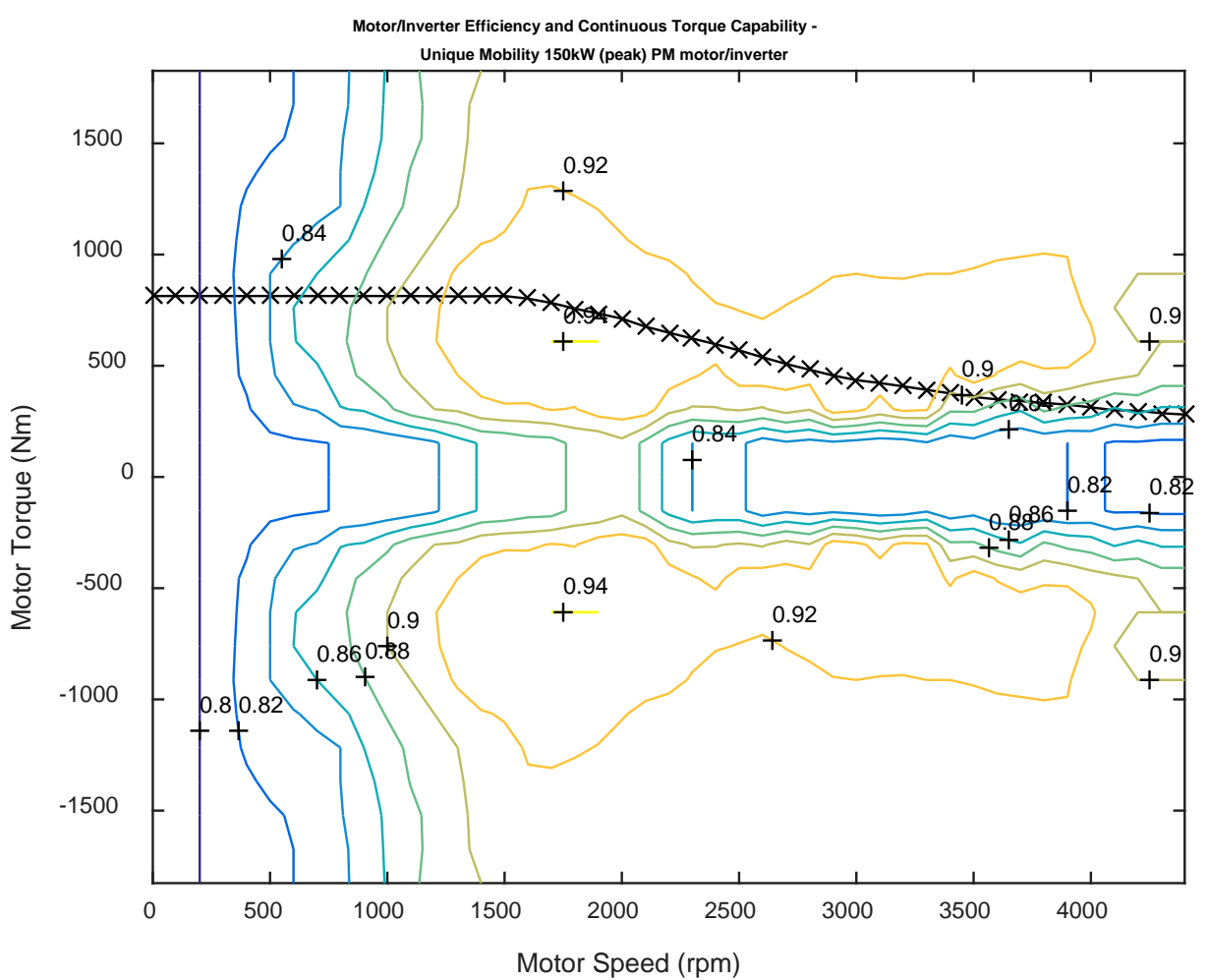

(a)

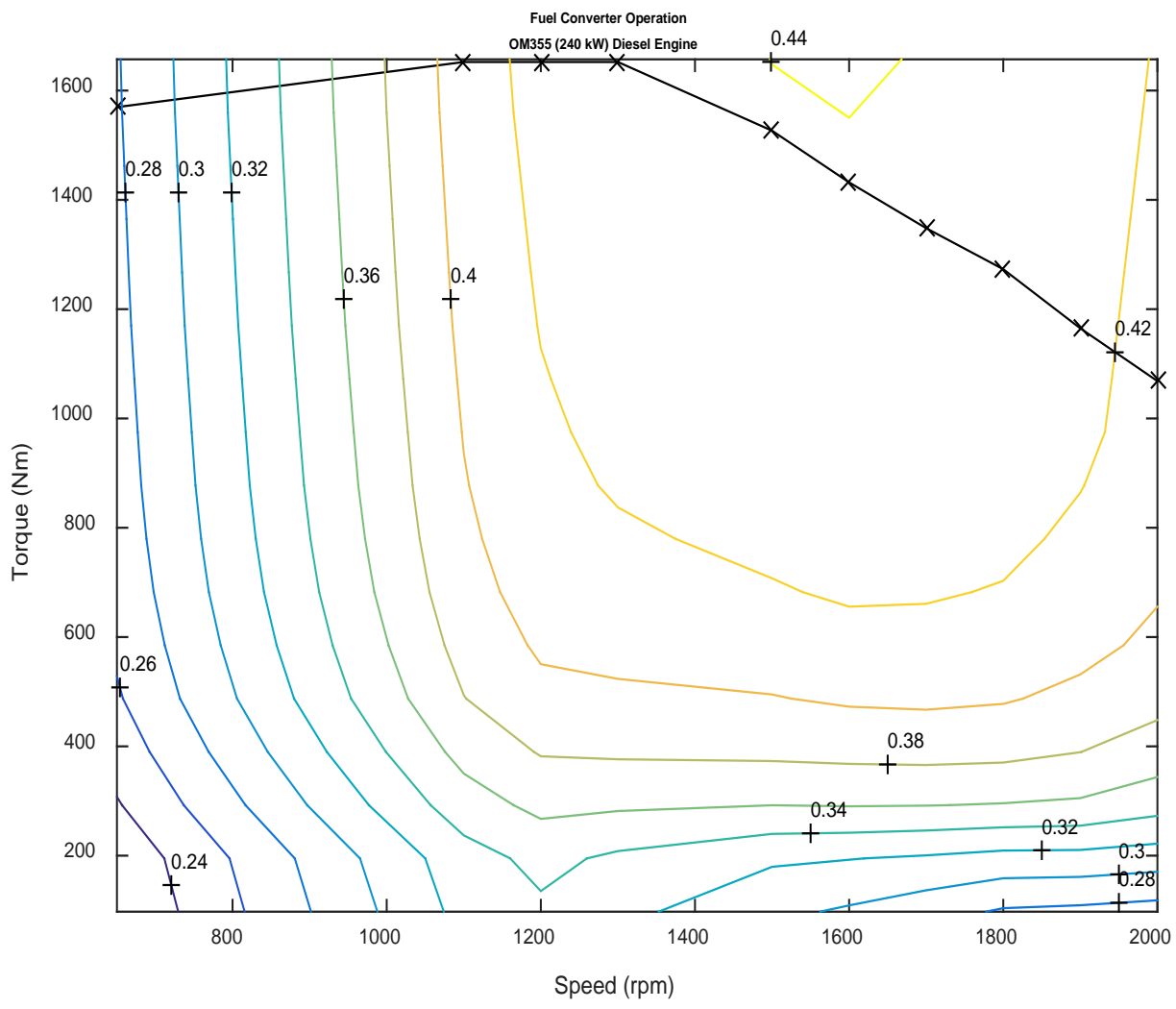

(b)

Figure 18. Functional areas of power transfer. 
Table 3. Comparison of fuel consumption and emissions.

\begin{tabular}{cccc}
\hline Type of boat & Normal & Hybrid & improvement percent \\
\hline Fuel consumption (litr) & 101 & 75 & $27 \%$ \\
(g/kW-hr) $\mathrm{SO}_{2}$ & 0.59 & 0.45 & $23 \%$ \\
(g/kW-hr) HC & 0.25 & 0.19 & $20 \%$ \\
(g/kW-hr)PM & 0.42 & 0.31 & $26 \%$ \\
(g/kW-hr) CO & 1.8 & 1.4 & $14 \%$ \\
\hline
\end{tabular}

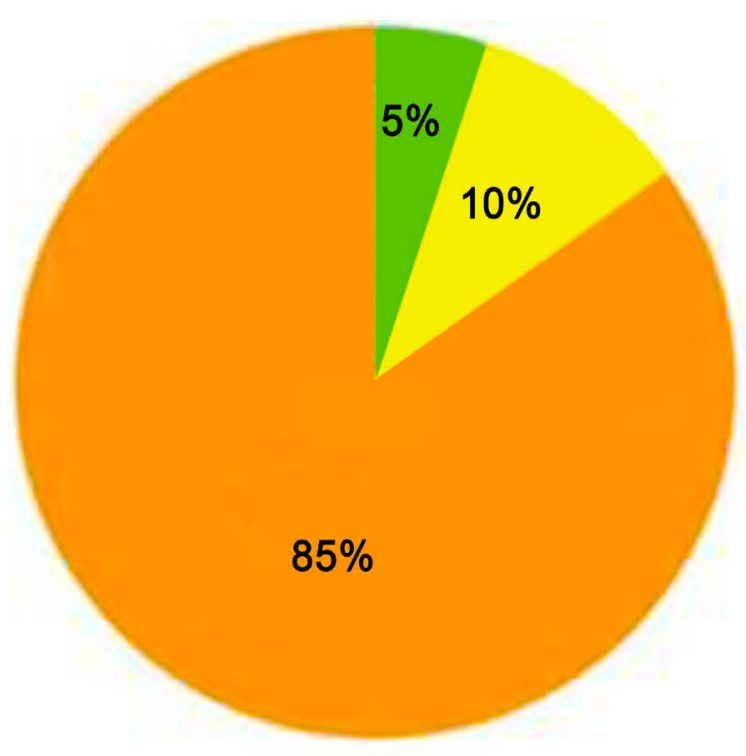

propulsion Price

\section{cost of maintenance and spare parts}

Figure 19. Comparison between diesel and hybrid systems.

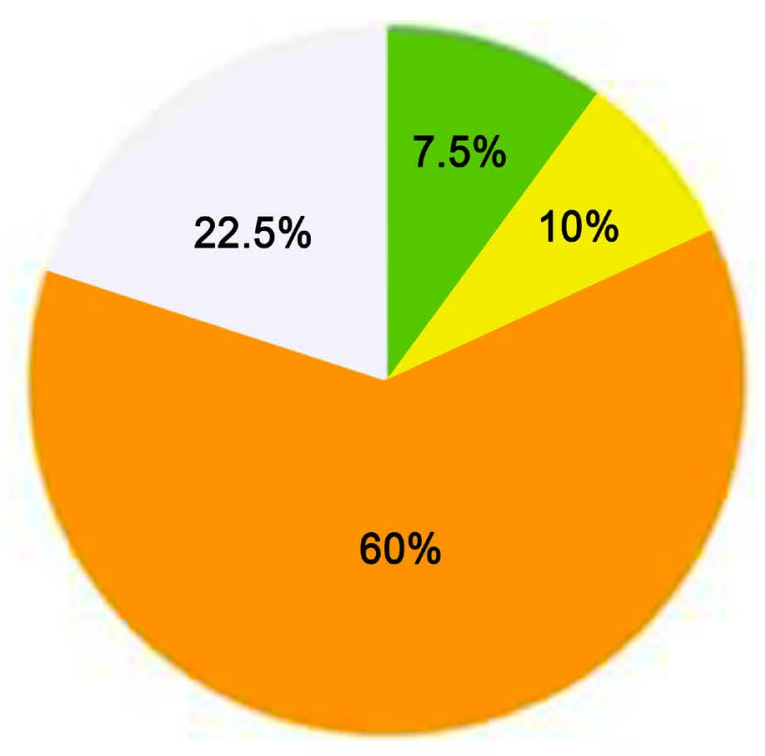

fuel cost

\section{decreasing fuel cost and emission}

for accurate determination of boat dynamic performance, a general idea will be introduced to researchers to evaluate the performance that is conducted by using simulation software to predict the amount of pollution and fuel consumption, before producing hybrid boat; so produced hybrid boat is suitable for different missions and maneuvers and is at the level of international standards. The results showed that the optimal hybridization of boats in addition to increasing the ability of boat to move can also reduce fuel consumption, air pollution emissions and noise.

\section{References}

[1] Abdel-Baki, A.S., Dkhil, M.A. and Al-Quraishy, S. (2011) Bioaccumulation of Some Heavy Metals in Tilapia Fish Relevant to Their Concentration in Water And Sediments of Wadi Hanifah, Saudi Arabia. African Journal of Biotechnology, 10, 2451-2541.

[2] Abdolahpur Monikh, M., Safahieh, A., Savari, A. and Doraghi, A. (2013) Heavy Metal Concentration in Sediment, Benthic, Benthopelagic, and Pelagic Fish Species from Musa 
Estuary (Persian Gulf). Environmental Monitoring and Assessment, 185, 215-222. http://dx.doi.org/10.1007/s10661-012-2545-9

[3] Agah, H., Leermakers, M., Marc Elskens, S. and Fatemi, M. (2009) Accumulation of Trace Metals in the Liver and Liver Tissues of Five Species from the Persian Gulf. Environmental Monitoring Assess, 157, 499-514.

[4] Agah, H.S., Hashtroodi, M. and Baeyens, W. (2011) Trace Metals Analysis in the Sediments of the Southern Caspian Sea. Journal of the Persian Gulf (Marine Science), 2, 1-12.

[5] Agusa, T., Kunito, T., Tanabe, Sh. and Pourkazemi, M. (2004) Concentrations of Trace Elements in Muscle of Sturgeons in the Caspian Sea. Marine Pollution Bulletin, 49, 789800. http://dx.doi.org/10.1016/j.marpolbul.2004.06.008

[6] Akin, H.K. and Unlu, E. (2007) Heavy Metal Concentrations in Water, Sediment, Fish and Some Benthic Organisms from Tigris River, Turkey. Environmental Monitoring and Assessment, 131, 323-337. http://dx.doi.org/10.1007/s10661-006-9478-0

[7] Alipour, H. and Pourkhabbaz, A. (2013) Assessing of Heavy Metal Concentration in the Tissues of Rutilus rutilus caspicus and Neogobius gorlap from Miankaleh. Bulletin of Environmental Contamination and Toxicology, 91, 517-521. http://dx.doi.org/10.1007/s00128-013-1105-5

[8] Allen G.P., Salomon, J.C., Bassoulct, P., Du Penhoat, Y. and De Grandpre, C. (1980) Effects of Tides on Mixing and Suspendcd Sediment Transport in Macrotidal Estuaries. Sedimentary Geology, 26, 69-90. http://dx.doi.org/10.1016/0037-0738(80)90006-8

[9] Al-Yousuf, M.H., El-Shahawi, M.S. and Al-Ghais, S.M. (2000) Trace Metals in Liver, Skin and Muscle of Lethrinus lentjan Fish Species in Relation to Body Length and Sex. Science of The Total Environment, 256, 87-94.

[10] Aly Salem D.M.S, Khaled. A, El Nemr A. and El-Sikaily, A. (2014) Comprehensive Risk Assessment of Heavy Metals in Surface Sediments along the Egyptian Red Sea Coast. Egyptian Journal of Aquatic Research, 40, 349-362. http://dx.doi.org/10.1016/j.ejar.2014.11.004

[11] Amiard, J., Amiardtriquet, C., Barka, S., Pellerin, J. and Rainbow, P. (2006) Metallothioneins in Aquatic Invertebrates: Their Role in Metal Detoxification and Their Use Asbiomarkers. Aquat.Toxicol.76, 160-202. Nile in Upper Egypt. International Journal of Environmental Science and Engineering (IJESE), 3, 1-10. http://dx.doi.org/10.1016/j.aquatox.2005.08.015

[12] Asuquo, F.E., Ewa-Oboho, I., Asuquo, E.F. and Udo, P.J. (2004) Fish Species Used as Biomarker for Heavy Metal and Hydrocarbon Contamination for Cross River, Nigeria. The Environmentalist, 2, 29-37. http://dx.doi.org/10.1023/B:ENVR.0000046344.04734.39

[13] Bahnasawy, M., Khidr, A. and Dheina, N. (2009) Seasonal Variations of Heavy Metals Concentrations in Mullet, Mugil cephalus and Liza ramada (Mugilidae) from Lake Manzala, Egypt. Journal of Applied Sciences Research, 5, 845-852.

[14] Berge, J.A. and Brevik, E.M. (1996) Uptake of Metals and Persistent Organochlorines in Crabs (Cancer pagurus) and Flounder (Platichthys flesus) from Contaminated Sediments: mesocosm and field experiments. Marine Pollution Bulletin, 33, 46-55. http://dx.doi.org/10.1016/S0025-326X(96)00144-0

[15] Buccolieri, A., Buccolieri, G., Cardellicchio, N., Dell'Atti, A., Di Leo, A. and Maci, A. (2006) Heavy Metals in Marine Sediments of Taranto Gulf (Ionian Sea, Southern Italy). Marine Chemistry, 99, 227-235. http://dx.doi.org/10.1016/j.marchem.2005.09.009 
Submit or recommend next manuscript to SCIRP and we will provide best service for you:

Accepting pre-submission inquiries through Email, Facebook, LinkedIn, Twitter, etc. A wide selection of journals (inclusive of 9 subjects, more than 200 journals)

Providing 24-hour high-quality service

User-friendly online submission system

Fair and swift peer-review system

Efficient typesetting and proofreading procedure

Display of the result of downloads and visits, as well as the number of cited articles

Maximum dissemination of your research work

Submit your manuscript at: http://papersubmission.scirp.org/

Or contact ojms@scirp.org 